\title{
Some Mechanism Seaweeds Employ to Cope with Salinity Stress in the Harsh Euhaline Oceanic Environment
}

\author{
Vincent van Ginneken \\ Blue Green Technology Foundation, Heelsum, Netherlands \\ Email: vvanginneken@hotmail.com
}

How to cite this paper: van Ginneken, V. (2018) Some Mechanism Seaweeds Employ to Cope with Salinity Stress in the Harsh Euhaline Oceanic Environment. American Journal of Plant Sciences, 9, 1191-1211. https://doi.org/10.4236/ajps.2018.96089

Received: February 9, 2018

Accepted: May 18, 2018

Published: May 21, 2018

Copyright $\odot 2018$ by author and Scientific Research Publishing Inc. This work is licensed under the Creative Commons Attribution International License (CC BY 4.0).

http://creativecommons.org/licenses/by/4.0/

(c) (i) Open Access

\begin{abstract}
In order to prevent salt damage because seaweed enzymes can only operate under hypohaline conditions (salinity $\approx 6 \%$ - 12\%o) but also obtain for photosynthesis an in the aquatic environment-due to a 10,000 fold strongly limited carbon source-seaweeds developed several mechanisms to meet these vital demands for survival in the harsh euhaline oceanic environment (salinity range: $32 \%$ - $35 \%$ ), we tested this range of adaptation mechanisms in the euhaline oceanic collected water in combination with the seaweed moisture. We obtained under laboratory conditions at 10 bar mechanical pressure for four seaweed species: Ulva lactuca, Caulerpa sertularioides, Caulerpa cf. brachypus (all three green) and Undaria pinnatifidia (brown). Oceanic water and seaweed moisture were measured for salinity, $\mathrm{pH}$ and by Inductively Coupled Plasma Spectroscopy (ICP)-techniques concentrations for macro-elements: $(\mathrm{Ca}, \mathrm{Fe}, \mathrm{K}, \mathrm{Mg}, \mathrm{Mn}, \mathrm{Na}, \mathrm{P}, \& \mathrm{~S})$, micro-elements $\approx[\mathrm{HM}]:(\mathrm{Al}, \mathrm{As}, \mathrm{Cd}, \mathrm{Co}, \mathrm{Cr}$, $\mathrm{Cu}, \mathrm{Mo}, \mathrm{Ni}, \mathrm{Pb} \& \mathrm{Zn}$ ) and nutrients (N-total \& $\mathrm{P}$-total). The [seawater compound $\mathrm{X}] /[$ oceanic compound $\mathrm{X}]$ ration is a reflection of an inward (uptake) or excretion mechanism over the seaweed cellular membrane which is operative. Our observations gave a clear dispersion to salinity stress with on one hand the green seaweed $U$. lactuca and on the other the brown seaweed $U$. pinnatifidia. Both Caulerpa spp. took in an intermediate position. Observed in compensatory responses to salinity stress was ranging Ulva $s p$. both Caulerpa spp.-Undaria sp.: 1) amount pressed seaweed moisture: [ml/g Fresh Weight]; 2) salinity: (in \%o); 3) $\mathrm{Na}^{+}$storage vacuole volume; 4) $\mathrm{Na}^{+}: \mathrm{K}^{+}$ratio (reflection of $\mathrm{K}^{+}$as osmolyticum); 5) $\Sigma[\mathrm{HM}]$ (as osmolyticum); 6) $\mathrm{pH}$ (seaweed moisture); 7) Nutrients ( $\& \mathrm{P}$ ); 8) availability of essential metal elements for plants $(\mathrm{Cu}, \mathrm{Fe}, \mathrm{Zn}, \mathrm{Mn}, \mathrm{Mo}, \mathrm{Ni})$; 9) transport direction of microand macro-elements. Finally, the role of brown vs. green seaweeds in the evolutionary eukaryotic tree of life in relation to the ability of the brown seaweeds to produce their own osmolyticum will be discussed.
\end{abstract}




\section{Keywords}

Seaweeds, Ulva lactuca, Caulerpa sertlatiodes and Caulerpa brachypus,

Undaria pinnatifididia, Seaweed Moisture, Sodium Extrusion, Desalination

Capacity, Inductively Coupled Plasma Spectroscopy (ICP)

\section{Introduction}

At present, terrestrial agriculture is at its limits mainly for available land area and fertilizers (reviewed: [1] [2]). Due to an unfettered population growth estimated at around 9.5 billion people at the midst of the $21^{\text {st }}$ century [3], a looming fertilizer (phosphorus) crisis [4], and lack of available land area to expand terrestrial agriculture [5], we have to go sea-farming [6].

This shift "towards a seaweed-based economy" [2] has tremendous opportunities and challenges because the Earth's surface is for $\approx 70.8 \%$ covered with water [7] while of the remaining terrestrial only $13.31 \%$ is arable [8]. In these oceans seaweeds and other marine plants are the primary producers in the marine environment. They form the standing crop and determine the productivity of all communities. Seaweed-based ecosystems are amongst the most productive on Earth [9]. In addition, global seaweed production by aquaculture is boosting as depicted in Figure 1 based on FAO 2014 data. Recently, we explained in great extent the "seaweed-paradox": which implies that biomass production is severely hampered by a 10,000 fold slower diffusion rate of a Carbon source or Dissolved Inorganic Carbon (DIC) in the biophysical medium water in comparison to terrestrial C3 crops [10]. Despite this negative property, pelagic seaweeds outcompete C3 crops for annual green biomass. However, for global biomass production, seaweeds produce only a small fraction of the global supply of biomass with below $30 \times 10^{6}$ fresh weight (FW) ton of seaweed, in comparison to $16 \times 10^{11}$ ton of terrestrial crops, grasses and forests [11].

In this research we will focus on the salt extrusion mechanism of the seaweeds, without an efficient aquatic photosynthesis which would be impossible [10]. Salt-damage is very harmful and even life threatening for terrestrial plants as outlined by [12] [13]. However, it might be possibly surprising that our marine seaweeds, inhabiting our oceans, also have a limited salt tolerance [14] and also have to cope with salt stress. Major reason is that the enzymes of seaweeds only can operate under hypohaline conditions [salinity $\approx 6 \%$ - $12 \%$ ], see [15] Material \& Methods]. Via several desalination mechanisms they succeed to survive in the harsh euhaline oceanic environment. Consequently, seaweeds in the harsh euhaline oceans must undergo osmotic adjustment involving, in part, the localization of toxic ions (typically $\mathrm{Na}^{+}$and $\mathrm{Cl}^{-}$) into vacuoles away from important metabolic processes located within the cytoplasm, as described for terrestrial plants exposed to salinity stress [12]. Unlike $\mathrm{Na}^{+}$which can adversely affect both catabolism and metabolism, $\mathrm{K}^{+}$is essential for maintaining osmotic balance, and 


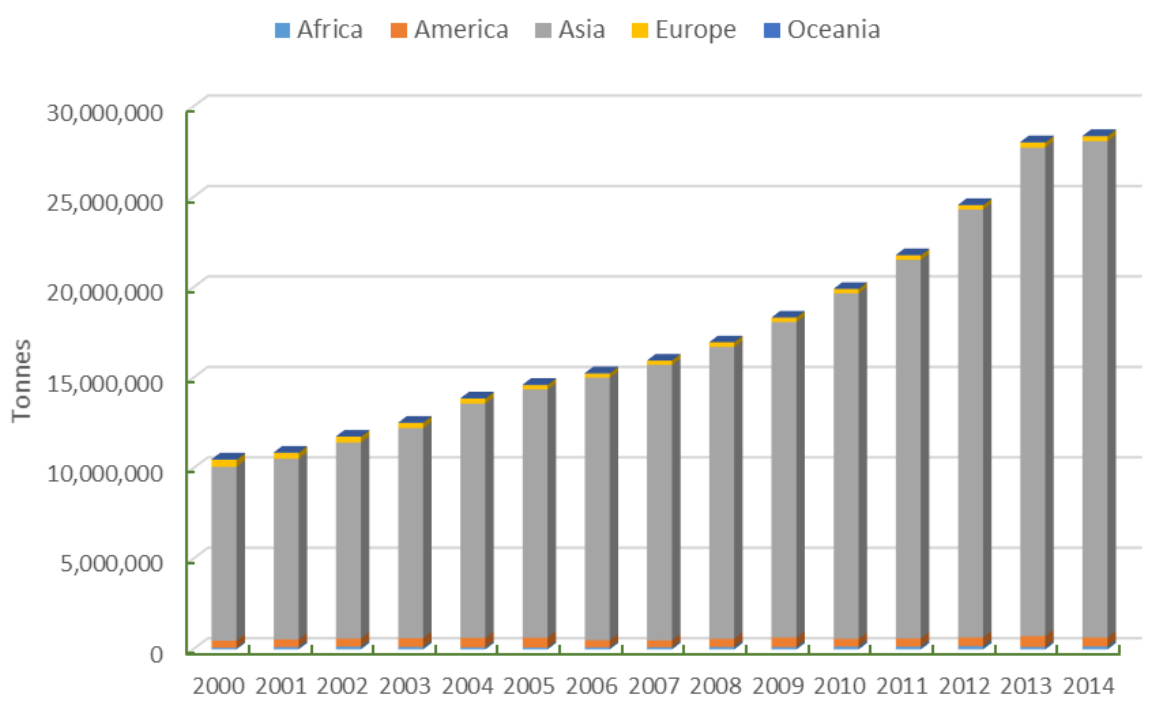

Figure 1. This graph shows the cumulative annual world aquatic plant production ( $\approx$ mainly seaweeds) (in tonnes) from FAO data (2014) over the past decade. Almost $95 \%$ of the global production is currently from Asia (Courtesy: Elisa Capuzzo, gov.uk, Marine Science).

supporting biological reactions as co-factors for numerous vital enzymes. Therefore, the uptake and assimilation of $\mathrm{K}^{+}$are imperative for overall plant health and growth. However, $\mathrm{Na}^{+}$competes with $\mathrm{K}^{+}$for intracellular influx, such that many $\mathrm{K}^{+}$transport systems tend to also have high affinities for $\mathrm{Na}^{+}$and thus function as $\mathrm{Na}^{+} / \mathrm{K}^{+}$symporters [16]. Therefore, relatively high environmental $\mathrm{Na}^{+}$levels can influence $\mathrm{K}^{+}$influx efficiencies in marine plants. A second adaptation mechanism in order to avoid salinity stress is via an ATP-driven $\mathrm{Na}^{+} / \mathrm{K}^{+}$ pump. This actively $\mathrm{Na}^{+} / \mathrm{K}^{+}$pump has two functions: 1) $\mathrm{Na}^{+}$sequestering in vacuoles in the seaweed itself in cell-to-cell interaction. 2) In support of $\mathrm{Na}^{+}$accumulation in intracellular vacuoles the pump also actively serves to excrete sodium to the oceanic environment in exchange for an osmolyticum acting compound in order to maintain cellular homeostasis. For both mechanisms in seaweeds, $\mathrm{H}^{+}$ATPase driven pumps mediate the translocation of $\mathrm{H}^{+}$and $\mathrm{K}^{+} / \mathrm{Na}^{+}$. It is assumed the milieu interior of a seaweed with contains clearly visible the vacuole for sequestering abundant sodium ions and/or abundant metallic cations (Heavy Metals) which in some seaweed species can be taken up from the oceanic environment in order to act as "substitute-osmolyticum" to compensate $\mathrm{Na}^{+}$-extrusion. Based on this model the vacuole is distinctly separated from chloroplast and mitochondrion essential biochemical pathways and vital enzyme systems and also the nucleus with its vulnerable DNA related processes. Third, as compensation mechanism to sodium extrusion seaweeds also can take up remarkably high $\mathrm{K}^{+}$levels from the oceanic environment acting in some seaweeds as the major of osmolyticum. Supportive evidence for this statement is given in Table 1 where can see that the mean $\left[\mathrm{Na}^{+}: \mathrm{K}^{+}\right]$ration is around 1.25 which suggest that remarkable high amounts of $\mathrm{K}^{+}$are taken up from the oceanic 
Table 1. Sodium and potassium levels ( $\mathrm{mg}^{-\mathrm{g}^{-1}} \mathrm{dry}$ weight) observed in different seaweeds.

\#: Definition according to [15].

\begin{tabular}{|c|c|c|c|c|c|c|}
\hline Seaweed Species & $\begin{array}{c}\mathrm{Na}^{+} \\
\left(\mathrm{mg} \cdot \mathrm{g}^{-1}\right)\end{array}$ & $\begin{array}{c}\mathrm{K}^{+} \\
\left(\mathrm{mg} \cdot \mathrm{g}^{-1}\right)\end{array}$ & {$\left[\mathrm{Na}^{+}: \mathrm{K}^{+}\right]$} & Tissue type & $\begin{array}{c}\text { Salinity } \\
\left.\text { (euhaline }{ }^{\#}\right)\end{array}$ & Reference \\
\hline Chondrus crispus & 42.7 & 31.8 & 2.28 & Whole plant & Seawater & [18] \\
\hline Fucus vesiculosus & 54.7 & 43.2 & 2.15 & Whole Plant & Seawater & [18] \\
\hline Laminaria digitata & 38.2 & 115.8 & 0.56 & Whole plant & Seawater & [18] \\
\hline Porphyra tenera & 36.3 & 35.0 & 1.77 & Whole plant & Seawater & [18] \\
\hline Sargassum mangarevense & 14.6 & 70.2 & 0.35 & Whole plant & Seawater & [19] \\
\hline Turbinaria ornate & 19.3 & 112.2 & 0.29 & Whole plant & Seawater & [19] \\
\hline Undaria pinnatifida & 70.6 & 86.9 & 1.38 & Whole plant & Seawater & [18] \\
\hline Mean \pm STD & \multicolumn{6}{|c|}{$39.5 \pm 7.370 .7 \pm 13.41 .25 \pm 0.32$} \\
\hline
\end{tabular}

environment as kind of osmolyticum [Note: the $\mathrm{Na}^{+} \& \mathrm{~K}^{+}$composition of seawater is respectively 19.3 and $0.4 \mathrm{mg} \cdot \mathrm{ml}^{-1}$ at $35 \mathrm{psu}$ respectively which gives an $\left[\mathrm{Na}^{+}: \mathrm{K}^{+}\right]$ration of $\approx 48.25[17]$.

In the review article of [20] for terrestrial plants the four ions involved in active ATP-ase dependent plasma membrane transport mechanism are given. These are given $\mathrm{H}_{3} \mathrm{O}^{+}, \mathrm{Na}^{+}, \mathrm{K}^{+}$, and $\mathrm{Ca}^{2+}$. This is the first report that mentions major differences in $\left[\mathrm{Na}^{+}: \mathrm{K}^{+}\right]$molar ration among seaweed species within their cytoplasma. For seaweeds until now only an ATP-driven $\left[\mathrm{Na}^{+}: \mathrm{K}^{+}\right]$pump has been described [21] [22]. The major transport proteins/channels are: 1) Sodium-Potassium pump, 2) antiporters, 3) channels, and 4) symporters who described these mechanisms for terrestrial plant [20]. If an organism uses a chemical faster than it can be delivered through this layer, it will become physically limited. Similarly, if an organism excretes a metabolic by-product into this Diffusion Boundary Layer (DBL) faster than it can diffuse out, then an elevated concentration of that bi-product will occur in the water next to the tissue surface. In this research manuscript we described the mechanism(s) of salt extrusion and coping with salt stress of seaweeds and some of the plant physiological mechanisms to remain in ionic homeostasis. Basic principle of this whole $\mathrm{Na}^{+}$ extrusion mechanism of seaweeds is that in order to prevent salt damage at seaweeds -considering the fact that their enzymes can only operate under hypohaline conditions (salinity $\approx 6 \%$ - 12\%o; Table 3 [15]). We hypothesize all kinds of compensation mechanisms needs to be (partly) operative to remain osmotic homeostasis in the seaweed cell. Various intracellular and extracellular compounds might play a role in the $\mathrm{Na}^{+}$extrusion mechanisms which are of essence so that the seaweed enzymes can operate under brackish intracellular seaweed cell conditions. Theoretically, kinds of mechanisms can serve as counteracting mechanism so that the seaweed cell after sodium extrusion remains osmotically in equilibrium [23]. However, it is not an overall compensation mechanism. Because around 10,000 seaweed species inhabit our oceans we hypothesize differ- 
ent mechanisms can be expected, dependent on the seaweed species. In this manuscript we will outline some of these mechanisms.

\section{Material \& Methods}

\section{Seaweeds:}

- Ulva lactuca (Chlorophyta): Katse Heule, Eastern Scheldt, The Netherlands; approximate coordinates: $51^{\circ} 32^{\prime} 30 \mathrm{~N}$ and $3^{\circ} 52^{\prime} \mathrm{E}$.

- Caulerpa sertularioides (Chlorophyta): purchased by Burgers' Zoo, Arnhem, (the Netherlands) Origin: Denpassar, Bali, Indonesia: approximate coordinates: $8^{\circ} 41^{\prime} \mathrm{S}$ and $115^{\circ} 17^{\prime} \mathrm{E}$.

- Caulerpa cf. brachypus (Chlorophyta): was obtained from "De Jong Marinelife", Spijk, (The Netherlands) Origin: Havanna, Cuba: approximate coordinates: $23^{\circ} 50^{\prime} \mathrm{S}$ and $82^{\circ} 50^{\prime} \mathrm{W}$.

- Undaria pinnatifidia (Wakame) (Phaeocophycea): Kilcar, West Donegal, Ireland, approximate coordinates: $54^{\circ} 37^{\prime} \mathrm{N}$ and $8^{\circ} 37^{\prime} \mathrm{W}$.

While seaweeds were collected, a water sample of the surrounding oceanic water was sampled at the same time stored at $-80^{\circ} \mathrm{C}$ pending analysis.

Sampling of four seaweeds including surrounding oceanic water was performed during the months June-September in the year 2016.

\section{Dry weight seaweeds:}

After collection, the seaweeds were brought as soon as possible to the laboratory. Most epiphytic material was removed; the seaweeds were rinsed quickly with freshwater, air-dried, oven-dried (one night at $60^{\circ} \mathrm{C}$ and one night at $105^{\circ} \mathrm{C}$ ), weighed and the dry matter content calculated.

\section{Experimental set up:}

In this experiment we determined for four seaweed species under mechanical pressure until 10 barr (see further) the percentage of moisture weight. Also the dry weight of the seaweeds was determined in an oven overnight (see above) In the freshly collected seaweed moisture we determined directly the salinity (in \%o) and the osmolarity (EC-value) expressed in $[\mathrm{mS} / \mathrm{cm}]$. Also the $\mathrm{pH}$ of oceanic water and seaweed moisture were determined with a $\mathrm{PHH}-7011 \mathrm{pH}$ meter with automatic temperature compensation (Omega, the Netherlands) Thereafter the obtained seaweed moisture was immediately stored at $-80^{\circ} \mathrm{C}$ pending analysis of micro- \& macro-elements. Microelements $\approx$ heavy-metals $=[\mathrm{HM}]$, (Al, As, Cd, Co, Cr, Cu, Mo, $\mathrm{Ni}, \mathrm{Pb} \& \mathrm{Zn}$ ) and macro-elements ( $\mathrm{Ca}, \mathrm{Fe}, \mathrm{K}, \mathrm{Mg}$, $\mathrm{Mn}, \mathrm{Na}, \mathrm{P}, \& \mathrm{~S})$ were measured by Inductively Coupled Plasma Spectroscopy (ICP) techniques at the central Chemical Biological Laboratory for Soil \& Water Research at Wageningen University (details see further) The earlier mentioned simultaneously with the seaweeds sampled oceanic water was directly deep frozen but now in conjunction with the samples of the seaweeds in a similar way ICP analyzed. This approach justifies a simultaneously comparison of [micro-] \& [macroelements] of both compartments (seaweed moisture versus oceanic water). From these laboratory measurements we calculated parameters which 
might be important in elucidating the complex sodium extrusion mechanism of the four investigated seaweeds.

Mechanical pressure procedure: To be able to produce press moisture from the seaweeds, the plant material $(300-1000 \mathrm{~g})$ was first pulped using a laboratory homogenizer (manufacturer: Foss Tecator, type: Tecator 1094 Homogenizer,), with either a smooth or a serrated knife, at s speed of $1500 \mathrm{rpm}$ or $3000 \mathrm{rpm}$. Moisture was pressed out of the pulp, approximately $100 \mathrm{~g}$ of pulp was used, using a LLOYD INSTRUMENTS (type: LR30K) testing machine that was fitted with a specially constructed unit for pressing pulps at a maximum pressure of 60 bar. Final weight of press cake and press moisture was determined. Afterwards press cake and samples of the obtained seaweed moisture of the four different seaweed species ( $\mathrm{n}=4$ per seaweed species) were immediately stored at $-80^{\circ} \mathrm{C}$ pending analyses.

Determination of micro- and macro-elements by Inductively Coupled Plasma spectroscopy (ICP-techniques):

1) $\mathrm{Al}, \mathrm{As}, \mathrm{Ca}, \mathrm{Cd}, \mathrm{Cr}, \mathrm{Cu}, \mathrm{Fe}, \mathrm{K}, \mathrm{Mg}, \mathrm{Mn}, \mathrm{Na}, \mathrm{Ni}, \mathrm{P}, \mathrm{Pb}, \mathrm{S}$ and $\mathrm{Zn}$ in seaweed moisture and in the sample of the surrounding waters were measured on an ICP-AES (Thermo Iris) according pretreatment SWV E-3404, measurement SWV E-1304 and conservation SWV E-3404 guide lines at the Chemical Biological Laboratory for Soil \& Water Research, Wageningen University, Wageningen (The Netherlands).

2) As, B, Ba, Cd, Co, Cr, Cu, La, Li, Mn, Mo, Ni, Pb, Sb, Se, Sn, and V in seaweed moisture and in the sample of the surrounding waters were measured on an HR-ICP-MS (Thermo Element 2) according pretreatment SWV E-3404, measurement SWV E-1325 and conservation SWV E-3404 guidelines at the same laboratory.

Salinity \& pH measurements: Salinity of the seaweed moisture and oceanic water were determined using an EC meter (manufacturer: WTW; type Cond 315i/SET) fitted with a conductivity cell (manufacturer: WTW; type: TetraCon 325 , cell constant $0.475 \mathrm{~cm}^{-1}$ ). The $\mathrm{pH}$ of seaweed moisture and oceanic water were determined with a $\mathrm{PHH}-7011 \mathrm{pH}$ meter with automatic temperature compensation (Omega, the Netherlands).

\section{Classification salinity:}

Classification in a certain salt range and terminology will be based on the ([15], Table 2) while classification of water sources to define the term "salinity" and elucidate words like Fresh, Brackish and Sea water salinity with TDS $\approx$ "total dissolved solids" expressed in milligrams per liter (mg/l) ([24], Table 3).

$\mathrm{N}$-total and P-total measurements: $\mathrm{N}$-total and $\mathrm{N}-\mathrm{NH}_{4}$ measurement were performed on a Segmented Flow Analyzer (SFA) apparatus according to SWV E1417 guide lines at the Chemical Biological Laboratory for Soil Research, Wageningen University, Wageningen (The Netherlands) Determination of P3 was performed on an HR-ICP-MS (Thermo Element-2) according pretreatment SWV E-3404, measurement SWV E-1325 and conservation SWV E-3404 guide lines at the same laboratory. 
Table 2. The Venice system gives specific words for salt concentration in linked to the corresponding salinity range (in \%o) [15].

\begin{tabular}{cc}
\hline Zone & Salinity range (in \%) \\
\hline Limnetic & $<0.5$ \\
$\beta$-Oligohaline & $0.5-3$ \\
$\alpha$-Oligohaline & $3-5$ \\
$\beta$-Mesohaline & $5-10$ \\
$\alpha$-Mesohaline & $10-18$ \\
Polymixohaline & $18-30$ \\
Euhaline & $30-40$ \\
Hyperhaline & $>40$ \\
\hline
\end{tabular}

Table 3. Classification of water sources to define the term "salinity" and elucidate words like Fresh, Brackish and Sea water salinity with TDS $\approx$ "total dissolved solids" expressed in milligrams per liter (mg/l) ([24]).

\begin{tabular}{cccc}
\hline Salinity content water & mg/l TDS & Definition & Salinity in \%o \\
\hline Drinking water & 500 & Consumption water & $0.5 \%$ o \\
Fresh water & Less than 1000 & Fresh water & $=1 \%$ o \\
Slightly saline & 1000 to 3000 & Brackish water & $1 \%$ - $3 \%$ o \\
Moderately saline & 3000 to 10,000 & Brackish water & $3 \%$ - $10 \%$ o \\
Highly saline & Over 10,000 & Brackish water & $>10 \%$ o \\
Oceanic water & 35,000 & Marine water & $35 \%$ o \\
\hline
\end{tabular}

\section{Calculations:}

1) $\mathrm{pH}=-\log _{10} \mathrm{H}^{+} \Leftrightarrow\left[\mathrm{H}^{+}\right]=10^{-\mathrm{pH}}[\mathrm{mol} / \mathrm{l}][25]$.

$\mathrm{pH}$-value and from this value calculated according to $10^{\mathrm{pH}}$ the amount of $\mathrm{H}^{+}$-ions in (mol/l) was calculated [25].

2) Accumulation factor $=\frac{\operatorname{Heavy}-m e t a l(H M) \text { in the seaweed moisture }}{\text { Heavy-metal }(\mathrm{HM}) \text { in the oceanic water }}$

3) $\mathrm{Na}^{+} / \mathrm{K}^{+}$ratio $=\mathrm{Na}^{+}(\mathrm{mg} / \mathrm{l}) / \mathrm{K}^{+}(\mathrm{mg} / \mathrm{l})$

\section{Weights and Volumes:}

The following weights and volumes were obtained from the overnight oven-dried seaweed material and the 10 bar mechanical pressed fresh seaweed biomass:

\section{*Oven-dried:}

4) Dry Weight $[\mathrm{g}]=\frac{\mathrm{W} \text {-tray oven dried material }[\mathrm{g}]-\mathrm{W} \text {-empty tray }[\mathrm{g}]}{\mathrm{W} \text {-tray with fresh material }[\mathrm{g}]-\mathrm{W} \text {-empty tray }[\mathrm{g}]}$

\section{*Mechanical Pressure:}

5) Total Moisture Weight $[\mathrm{g}]=($ Weight pressed moisture $[\mathrm{g}])+($ Losses moisture in machine $[\mathrm{g}])$.

6) With: Losses moisture in the machine $=\left(W_{\text {pulp }}[g]-W_{\text {press moisture }}[g]-W_{\text {press cake }}\right.$ 
[g]).

7) With: W = Weight in gram [g].

*Vacuole size cell:

Based on the following three assumptions that:

1) The whole seaweed cell vacuole is $100 \%$ filled with seaweed moisture (see Figure 2 left image);

2) At the applied 10 bar mechanical pressure procedure the whole volume of the seaweed cell vacuole will be squeezed empty;

3) $1 \mathrm{ml}$ seaweed moisture will weight 1 gram and has with a corresponding specific gravity of water a volume of one cubic $\mathrm{cm}$.

We will conclude that the calculated "Total Moisture Weight" in (g) will correspond to the volume of the seaweed cell vacuole.

\section{Results}

In Figure 2 the vacuole size for sequestering $\mathrm{Na}^{+}$and to some extent abundant metallic cations (HM) spatially separated from vital biochemical and physiological essential pathways. An impression per seaweed species for its water storage capacity in the vacuoles can be acquired from the [Wet-Weight/Dry-Weight] ration or [WW/DW]-ration. A high [WW/DW]-ration is a reflection of larger vacuoles for storage and the presence of a higher water content in the cell wall. The WW/DW ratio of the four seaweed-species used in this study is given in Table 4. The lowest WW/DW ratios were found for Ulva lactuca and Undaria pinnatifidia of respectively $4.95 \pm 0.11$ and $2.36 \pm 0.74$. The low WW/DW rations for both species are a reflection of a large vacuole capacity and thus of a high seaweed moisture storage capacity. For the two Caulerpa spp. the WW/DW ratios were 10 - 20 fold higher in the range $50-60$.

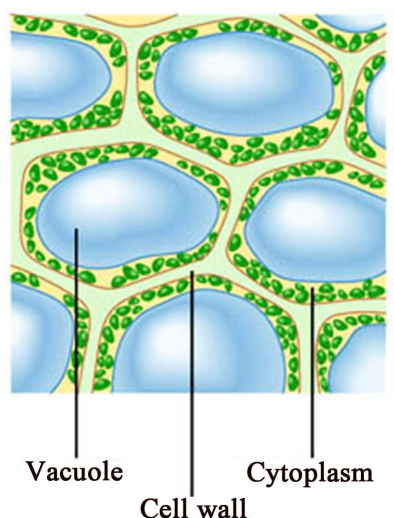

(a)

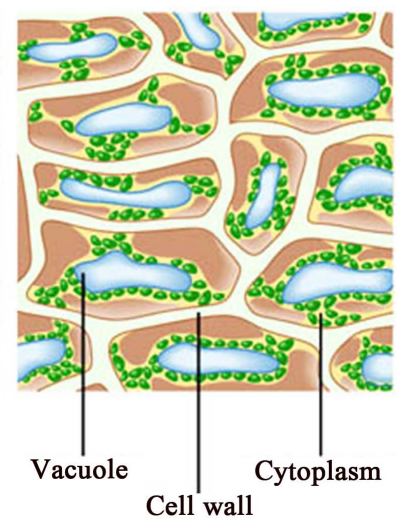

(b)

Figure 2. Example how vacuoles within the seaweed cell can contain large amount of (brackish) seaweed moisture. (a): Example of "healthy" cells of fresh seaweed biomass we used in our mechanical 10 bar laboratory pressure in order to obtain seaweed moisture. (b): Theoretical option for a non-salt adapted "unhealthy" seaweed-cells which are partly desiccated. (Source: courtesy Evert de Vries). 
Table 4. Some characteristics for the at 10 bar mechanical pressed seaweed moisture for four seaweed species, Ulva lactuca, Caulerpa sertlatiodes and Caulerpa cf. brachypus and the brown seaweed Undaria pinnatifidia found at different locations like: salinity, nutrients like $\mathrm{N} \& \mathrm{P}$, and $\mathrm{pH}$-value and from this value calculated according to $10^{\mathrm{pH}}$ the amount of $\mathrm{H}^{+}$-ions in (mol/l) was calculated [25]; mean \pm STD of $\mathrm{n}=4$ samples per seaweed species. B.D.L. = below detection limit $\approx 0.03 \mathrm{mg} / \mathrm{l}$. Definitions for salinity are: marine water: $3500 \mathrm{mg} / \mathrm{l}$ TDS; highly saline (brackish): over 10,000 mg/l TDS; moderately saline (brackish): 3000 to 10,000 mg/l TDS; slightly saline (brackish): 1000 To 3000 mg/l TDS; fresh water: less than $1000 \mathrm{mg} / \mathrm{l} \mathrm{TDS}$; drinking water $500 \mathrm{mg} / \mathrm{l}$ TDS (source: $[24]) . \Sigma[\mathrm{HM}]$ Is total sum of metallic cations ( $\approx$ Heavy metals) in seaweed moisture.

\begin{tabular}{|c|c|c|c|c|c|c|c|c|c|c|c|}
\hline $\begin{array}{c}\text { Seaweed } \\
\text { spp. }\end{array}$ & $\begin{array}{l}\text { Lab } \\
\text { No }\end{array}$ & $\begin{array}{l}\text { Calculated } \\
\text { Dry matter. } \\
\text { DW in }(\mathrm{g})\end{array}$ & $\begin{array}{c}\text { Calcul. } \\
\text { Total moist. } \\
\text { WW in (g) }\end{array}$ & WW/DW & $\begin{array}{c}\text { lab } \\
\text { salinity } \\
\text { prom. }\end{array}$ & $\begin{array}{c}\mathrm{lab} \\
\mathrm{EC} \\
\mathrm{mS} / \mathrm{cm}\end{array}$ & $\begin{array}{c}\text { lab } \\
\mathrm{pH} \\
\mathrm{mg} / \mathrm{l}\end{array}$ & $\begin{array}{l}\mathrm{Lab} \\
\mathrm{Na}+ \\
\mathrm{mg} / 1\end{array}$ & $\begin{array}{c}\text { Seaweed } \\
\sum[\mathrm{HM}] \\
\mathrm{mg} / 1\end{array}$ & $\begin{array}{c}\text { Ocean } \\
\Sigma[\mathrm{HM}] \\
\mathrm{mg} / 1\end{array}$ & $\begin{array}{l}\text { Lab } \\
\text { P-tot } \\
\mathrm{mg} / 1\end{array}$ \\
\hline Ulva & Zs1 & 9.37 & 47.19 & 5.04 & 9.60 & 14.77 & 5.08 & 40.90 & 94.20 & 420.00 & 88.90 \\
\hline lact. & Zs2 & 9.56 & 48.29 & 5.05 & 9.40 & 14.47 & 5.30 & 45.80 & 93.40 & 432.00 & 91.40 \\
\hline \multirow[t]{4}{*}{ NL } & Zs3 & 9.36 & 45.52 & 4.86 & 9.40 & 14.38 & 4.94 & 42.70 & 90.60 & 360.00 & 83.10 \\
\hline & Zs4 & 9.24 & 44.80 & 4.85 & 9.60 & 13.68 & 4.93 & 42.90 & 87.60 & 359.00 & 85.30 \\
\hline & Mean & 9.38 & 46.45 & 4.95 & 9.50 & 14.33 & 5.06 & 43.08 & 91.45 & 392.75 & 87.18 \\
\hline & Std. & 0.14 & 1.58 & 0.11 & 0.12 & 0.46 & 0.17 & 2.03 & 2.99 & 38.71 & 3.69 \\
\hline Caul. & Cs1 & 1.39 & 71.94 & 51.94 & 19.10 & 27.80 & 4.17 & 4.81 & 37.30 & 362.00 & 45.00 \\
\hline sert. & Cs2 & 1.29 & 70.17 & 54.40 & 19.50 & 28.30 & 4.20 & 4.61 & 38.20 & 344.00 & 45.00 \\
\hline \multirow[t]{4}{*}{ Bali } & Cs3 & 1.25 & 86.86 & 69.66 & 19.50 & 28.30 & 4.20 & 4.62 & 37.60 & 348.00 & 44.80 \\
\hline & Cs4 & 1.21 & 76.32 & 62.92 & 19.30 & 28.20 & 4.20 & 4.71 & 37.50 & 351.00 & 45.20 \\
\hline & Mean & 1.28 & 76.32 & 59.73 & 19.35 & 28.15 & 4.19 & 4.69 & 37.65 & 351.25 & 45.00 \\
\hline & Std. & 0.07 & 7.49 & 8.12 & 0.19 & 0.24 & 0.02 & 0.09 & 0.39 & 7.72 & 0.16 \\
\hline Caul. & $\mathrm{Ci}-1$ & 1.19 & 50.23 & 42.39 & 20.50 & 29.70 & 4.51 & 14.40 & 369.00 & 922.00 & 91.40 \\
\hline brach. & $\mathrm{Ci}-2$ & 1.25 & 52.05 & 41.54 & 20.60 & 29.70 & 4.51 & 14.50 & 374.00 & 917.00 & 92.80 \\
\hline \multirow[t]{4}{*}{ Cuba } & $\mathrm{Ci}-3$ & 1.13 & 57.47 & 50.81 & 20.70 & 29.90 & 4.50 & 14.60 & 377.00 & 920.00 & 92.50 \\
\hline & $\mathrm{Ci}-4$ & 1.17 & 53.25 & 45.40 & 20.50 & 29.80 & 4.51 & 14.70 & 374.00 & 917.00 & 93.40 \\
\hline & Mean & 1.19 & 53.25 & 45.03 & 20.58 & 29.78 & 4.51 & 14.55 & 373.50 & 919.00 & 92.53 \\
\hline & Std. & 0.05 & 3.08 & 4.19 & 0.10 & 0.10 & 0.00 & 0.13 & 3.32 & 2.45 & 0.84 \\
\hline Undar & Wa1 & 28.41 & 39.88 & 1.40 & 9.60 & n.d. & 6.53 & 14.60 & 0.00 & 123.00 & 17.80 \\
\hline Pinnat & $\mathrm{Wa} 2$ & 28.74 & 62.70 & 2.18 & 9.80 & n.d. & 6.44 & 10.10 & 0.00 & 96.60 & 12.60 \\
\hline \multirow[t]{4}{*}{ IR } & Wa3 & 27.22 & 83.03 & 3.05 & 9.80 & n.d. & 6.50 & 8.27 & 0.00 & 91.20 & 11.60 \\
\hline & Wa4 & 28.15 & 79.29 & 2.82 & 5.90 & n.d. & 6.57 & 5.92 & 0.00 & 83.10 & 10.60 \\
\hline & Mean & 28.13 & 66.22 & 2.36 & 8.78 & n.d. & 6.51 & 9.72 & 0.00 & 98.48 & 13.15 \\
\hline & Std. & 0.65 & 19.66 & 0.74 & 1.92 & n.d. & 0.05 & 3.67 & 0.00 & 17.27 & 3.21 \\
\hline
\end{tabular}

In Table 5 is the ability given to excrete sodium to the oceanic environment via active ATP-driven pumps like the $\mathrm{Na}^{+} / \mathrm{K}^{+}$-pump or solely an active $\mathrm{Na}^{+}$extrusion pump.

When considering the composition of $\mathrm{Na}^{+}$and $\mathrm{K}^{+}$in seawater $\left(19.3 \mathrm{mg} \cdot \mathrm{ml}^{-1}\right.$ and $0.4 \mathrm{mg} \cdot \mathrm{ml}^{-1}$ at $35 \mathrm{psu}$, respectively gives in this case an $\mathrm{Na}^{+} / \mathrm{K}^{+}$ratio of 48.25 seawater of [17]. In our studies for the Netherlands, Ireland, Cuba and Bali the $\mathrm{Na}^{+} / \mathrm{K}^{+}$ratio was in the range $26.1-33.3$ (Indonesia vs. Ireland Table 5) It is 
Table 5. Sodium and Potassium concentrations determined by Oceanic location. Left: Concentrations of the sodium and potassium ions in the oceanic water at the sampling location [in: $(\mathrm{mg} / \mathrm{l})]$ and its ration. Right: Concentrations of the sodium and potassium ions in the four seaweed-species at the sampling location [in: $(\mathrm{mg} / \mathrm{l})]$ and its ration. Values given in the Table are the values of one water sample and the mean value of one four seaweed 10 bar pressed subsamples.

\begin{tabular}{cccccccc}
\hline $\begin{array}{c}\text { Location } \\
\text { Ocean }\end{array}$ & $\begin{array}{c}\mathrm{Na}^{+} \\
(\text {mean })\end{array}$ & $\begin{array}{c}\mathrm{K}^{+} \\
(\text {mean })\end{array}$ & $\begin{array}{c}\mathrm{Na}^{+} / \mathrm{K}^{+} \\
(\text {mean })\end{array}$ & $\begin{array}{c}\text { Seaweed } \\
\text { species }\end{array}$ & $\begin{array}{c}\mathrm{Na}^{+} \\
(\text {mean })\end{array}$ & $\begin{array}{c}\mathrm{K}^{+} \\
(\text {mean })\end{array}$ & $\begin{array}{c}\mathrm{Na}^{+} / \mathrm{K}^{+} \\
(\text {mean })\end{array}$ \\
\hline Netherlands & 9983 & 321 & 31.1 & Ulva lactuca & 1363.0 & 1205.0 & 1.13 \\
Indonesia & 10020 & 384 & 26.1 & Caulerpa sert. & 6238.8 & 481.0 & 12.97 \\
Cuba & 10840 & 361 & 30.0 & Caulerpa brach. & 6678.5 & 675.5 & 9.89 \\
Ireland & 18230 & 547 & 33.3 & Undaria pinnat. & 3147.0 & 121.3 & 25.94 \\
\hline
\end{tabular}

clear that mechanisms must be in place to minimize cytosolic $\mathrm{Na}^{+}$accumulation while permitting necessary $\mathrm{K}^{+}$uptake. The dissimilarity between $\mathrm{Na}^{+}$and $\mathrm{K}^{+}$ concentrations in seawater at all four oceanic locations is $\approx 30$ with of course $\left[\mathrm{K}^{+}\right]$ $\approx 30$ fold lower. The $\left[\mathrm{Na}^{+}: \mathrm{K}^{+}\right]$molar ratio of our seaweeds was the lowest in the seaweed Ulva lactuca $\approx 1.13$ which is indicative that $\mathrm{K}^{+}$is in this green seaweed species acting as an important osmolyticum. The two Caulerpa spp. Are in the intermediate range of around $\approx 11.5$ (range 9.9 - 13.0), while in the brown seaweed Undaria pinnatifidia this value is around 26. For the latter species this implies that $\mathrm{K}^{+}$has no important role as major osmolyticum and give strong evidence that this brown seaweed is able to produce biochemically its own osmolyticum. In general, brown seaweeds are able to produce a large variation of economically important osmolyticuma. In general, these by brown seaweeds produced osmolyticuma are or from the carbohydrate fraction or phycocolloid fraction. Although we didn't measure any osmolyticum of one of these fractions in Undaria pinnatifidia this extremely high $\left[\mathrm{Na}^{+}: \mathrm{K}^{+}\right]$molar ratio of $\approx 26$ gives strongly evidence that this species is able to produce its own osmolyticum.

The moisture of seaweeds has a rather low salinity (brackish) in order of descending salinity (mean \pm std $(\mathrm{n}=4)$ in $\%$ ): Caulerpa cf. brachypus $\approx 20.58 \pm$ 0.096 (Polymixohaline); Caulerpa sertularioides $\approx 19.30 \pm 0.163$ (Polymixohaline); Ulva lactuca $\approx 9.501 \pm 0.115$ ( $\beta$-Mesohaline) and Undaria pinnatifidia $\approx$ $9.500 \pm 0.115$ ( $\beta$-Mesohaline) [15].

Ulva lactuca had the highest P-content $(69.7 \mathrm{mg} / \mathrm{l})$, Undaria pinnatifidia the lowest $(13.2 \mathrm{mg} / \mathrm{l})$ while both Caulerpa spp. had an intermediate position. $\mathrm{N}-\mathrm{NH}_{4}$ had the highest value in Ulva lactuca $(34.5 \mathrm{mg} / \mathrm{l})$ and the lowest in Caulerpa sertlatioides $(4.7 \mathrm{mg} / \mathrm{l})$ Interestingly $\mathrm{Nts}$ was the highest in Caulerpa $c f$. brachypus $(298.8 \mathrm{mg} / \mathrm{l})$ while was surprisingly zero in Undaria pinnatifidi (Tables 6-8).

\section{Discussion}

Excess salt is toxic for terrestrial plants but also for seaweeds living in the euhalien [15] oceanic environment. Seaweeds can employ a number of mechanisms 
Table 6. Macro-elements [MaE]: (cations \& anions) in seaweed moisture of four seaweed species [per species mean $\pm \mathrm{SD}, \mathrm{n}=4$ ), in a water sample $(n=1)$ of the ocean where they were collected and the seaweed/ocean ration for that macro-element. A ratio $>1$ for a specific $[\mathrm{MaE}]$ is indicative for a higher concentration in the seaweed moisture in comparison to the oceanic water so it can be sequestered (active or passive). Specific details are described in the M \& M section.

\begin{tabular}{|c|c|c|c|c|c|c|c|c|c|c|c|}
\hline $\begin{array}{c}\text { Sample } \\
\text { nr. }\end{array}$ & $\begin{array}{l}\text { Seaweed } \\
\text { Species }\end{array}$ & $\begin{array}{c}\mathrm{Ca}^{2+} \\
{[\mathrm{mg} / \mathrm{l}]}\end{array}$ & $\begin{array}{c}\mathrm{Fe}^{2+} \\
{[\mathrm{mg} / \mathrm{l}]}\end{array}$ & $\begin{array}{c}\mathrm{K}^{+} \\
{[\mathrm{mg} / \mathrm{l}]}\end{array}$ & $\begin{array}{l}\mathrm{Mg}^{2+} \\
{[\mathrm{mg} / \mathrm{l}]}\end{array}$ & $\begin{array}{c}\mathrm{Mn}^{2+} \\
{[\mathrm{mg} / \mathrm{l}]}\end{array}$ & $\begin{array}{c}\mathrm{Na}^{+} \\
{[\mathrm{mg} / \mathrm{l}]}\end{array}$ & $\begin{array}{l}\text { SUM MACRO } \\
\text { CATIONS }\end{array}$ & $\begin{array}{c}\mathrm{P}^{3-} \\
{[\mathrm{mg} / \mathrm{l}]}\end{array}$ & $\begin{array}{c}\mathrm{S}^{2-} \\
{[\mathrm{mg} / \mathrm{l}]}\end{array}$ & $\begin{array}{c}\text { SUM } \\
\text { MACRO } \\
\text { ANIONS }\end{array}$ \\
\hline & Threshold & 1.20 & 0.09 & 0.40 & 0.15 & 0.01 & 0.30 & & 0.10 & 0.20 & \\
\hline \multirow[t]{2}{*}{ 1) } & Ulva lactuca & 552.50 & 2.74 & 1205.00 & 1762.00 & 3.77 & 1363.00 & 4889.00 & 87.18 & 5493.25 & 5580.43 \\
\hline & & 20.70 & 0.40 & 34.29 & 47.85 & 0.16 & 26.26 & 121.42 & 3.69 & 87.55 & 86.47 \\
\hline \multirow[t]{2}{*}{ 2) } & Caulerpa sertlatiodes & 530.00 & 1.08 & 481.00 & 509.25 & 1.18 & 6238.75 & 7761.26 & 45.00 & 581.75 & 626.75 \\
\hline & & 25.47 & 0.04 & 5.35 & 9.03 & 0.03 & 92.33 & 115.76 & 0.16 & 155.56 & 155.56 \\
\hline \multirow[t]{2}{*}{ 3) } & Caulerpa cf. brach. & 440.00 & 0.90 & 675.50 & 776.00 & 2.05 & 6678.50 & 8572.95 & 92.53 & 1376.50 & 1469.03 \\
\hline & & 3.27 & 0.14 & 4.12 & 12.25 & 0.07 & 75.12 & 84.28 & 0.84 & 79.35 & 80.13 \\
\hline \multirow[t]{2}{*}{ 4) } & Undaria pinnatifidia & 110.50 & 0.25 & 121.25 & 327.50 & 0.02 & 3147.00 & 3706.52 & 13.15 & 345.50 & 358.65 \\
\hline & & 1.00 & 0.03 & 5.32 & 8.66 & 0.01 & 32.32 & 37.79 & 3.21 & 7.19 & 8.67 \\
\hline \multirow[t]{2}{*}{$\begin{array}{c}\text { Sample } \\
\text { nr. }\end{array}$} & $\begin{array}{l}\text { Four } \\
\text { Oceans }\end{array}$ & $\begin{array}{c}\mathrm{Ca}^{2+} \\
{[\mathrm{mg} / \mathrm{l}]}\end{array}$ & $\begin{array}{c}\mathrm{Fe}^{2+} \\
{[\mathrm{mg} / \mathrm{l}]}\end{array}$ & $\begin{array}{c}\mathrm{K}^{+} \\
{[\mathrm{mg} / \mathrm{l}]}\end{array}$ & $\begin{array}{l}\mathrm{Mg}^{2+} \\
{[\mathrm{mg} / \mathrm{l}]}\end{array}$ & $\begin{array}{l}\mathrm{Mn}^{2+} \\
{[\mathrm{mg} / \mathrm{l}]}\end{array}$ & $\begin{array}{c}\mathrm{Na}^{+} \\
{[\mathrm{mg} / \mathrm{l}]}\end{array}$ & $\begin{array}{l}\text { SUM MACRO } \\
\text { CATIONS }\end{array}$ & $\begin{array}{c}\mathrm{P}^{3-} \\
{[\mathrm{mg} / \mathrm{l}]}\end{array}$ & $\begin{array}{c}\mathrm{S}^{2-} \\
{[\mathrm{mg} / \mathrm{l}]}\end{array}$ & $\begin{array}{c}\text { SUM } \\
\text { MACRO } \\
\text { ANIONS }\end{array}$ \\
\hline & Threshold & 1.20 & 0.09 & 0.40 & 0.15 & 0.01 & 0.30 & & 0.10 & 0.20 & \\
\hline 1). & Netherlands & 291.00 & 0.09 & 321.00 & 1214.00 & 0.01 & 9983.00 & 11809.10 & 0.10 & 933.00 & 933.10 \\
\hline 2). & Indonesia & 313.00 & 0.09 & 384.00 & 1206.00 & 0.01 & 10020.00 & 11923.10 & 0.02 & 866.00 & 866.02 \\
\hline 3). & Cuba & 334.00 & 0.09 & 361.00 & 1336.00 & 0.01 & 10840.00 & 12871.10 & 0.79 & 983.00 & 983.79 \\
\hline 4). & Ireland & 473.00 & 0.09 & 547.00 & 2212.00 & 0.01 & 18230.00 & 21462.10 & 0.01 & 1683.00 & 1683.01 \\
\hline Mean & & 352.75 & 0.09 & 403.25 & 1492.00 & 0.01 & 12268.25 & 14516.35 & 0.23 & 1116.25 & 1116.48 \\
\hline Std & & 82.07 & 0.00 & 99.31 & 483.67 & 0.00 & 3994.14 & 4654.91 & 0.38 & 380.86 & 380.75 \\
\hline \multirow[t]{2}{*}{$\begin{array}{c}\text { Sample } \\
\text { nr. }\end{array}$} & $\begin{array}{c}\text { Ratio } \\
\text { seaweed/ocean }\end{array}$ & $\begin{array}{c}\mathrm{Ca}^{2+} \\
{[\mathrm{mg} / \mathrm{l}]}\end{array}$ & $\begin{array}{c}\mathrm{Fe}^{2+} \\
{[\mathrm{mg} / \mathrm{l}]}\end{array}$ & $\begin{array}{c}\mathrm{K}^{+} \\
{[\mathrm{mg} / \mathrm{l}]}\end{array}$ & $\begin{array}{l}\mathrm{Mg}^{2+} \\
{[\mathrm{mg} / 1]}\end{array}$ & $\begin{array}{c}\mathrm{Mn}^{2+} \\
{[\mathrm{mg} / \mathrm{l}]}\end{array}$ & $\begin{array}{c}\mathrm{Na}^{+} \\
{[\mathrm{mg} / \mathrm{l}]}\end{array}$ & $\begin{array}{l}\text { SUM MACRO } \\
\text { CATIONS }\end{array}$ & $\begin{array}{c}\mathrm{P}^{3-} \\
{[\mathrm{mg} / \mathrm{l}]}\end{array}$ & $\begin{array}{c}\mathrm{S}^{2-} \\
{[\mathrm{mg} / \mathrm{l}]}\end{array}$ & $\begin{array}{c}\text { SUM } \\
\text { MACRO } \\
\text { ANIONS }\end{array}$ \\
\hline & Threshold & 1.20 & 0.09 & 0.40 & 0.15 & 0.01 & 0.30 & & 0.10 & 0.20 & \\
\hline \multirow[t]{2}{*}{ 1) } & Ulva/ocean & 1.90 & 30.39 & 3.75 & 1.45 & 376.75 & 0.14 & 414.38 & 871.75 & 5.89 & 877.64 \\
\hline & & 0.07 & 4.48 & 0.11 & 0.04 & 16.07 & 0.00 & 14.50 & 36.94 & 0.09 & 36.92 \\
\hline \multirow[t]{2}{*}{ 2) } & Caulerpa sert./ocean & 0.35 & 2.73 & 0.32 & 0.27 & 2.05 & 0.31 & 6.04 & 657.50 & 0.40 & 657.90 \\
\hline & & 0.00 & 0.35 & 0.01 & 0.01 & 0.58 & 0.00 & 0.79 & 160.29 & 0.01 & 160.29 \\
\hline \multirow[t]{2}{*}{ 3) } & Caulerpa brach./ocean & 0.87 & 1.00 & 0.89 & 0.91 & 1.00 & 0.92 & 5.59 & 0.13 & 0.95 & 1.08 \\
\hline & & 0.00 & 0.00 & 0.00 & 0.00 & 0.00 & 0.00 & 0.00 & 0.00 & 0.00 & 0.00 \\
\hline \multirow[t]{2}{*}{ 4) } & Undaria/ocean & 0.66 & 1.00 & 0.70 & 0.55 & 1.00 & 0.55 & 4.46 & 2.00 & 0.51 & 2.51 \\
\hline & & 0.00 & 0.00 & 0.00 & 0.00 & 0.00 & 0.00 & 0.00 & 0.00 & 0.00 & 0.00 \\
\hline
\end{tabular}


Table 7. Microelements [MiE] (cations) in seaweed moisture of four seaweed species [per species mean $\pm S D, n=4$ ), in a water sample $(n=1)$ of the ocean where they were collected and the seaweed/ocean ration for that microelement. A ratio $>1$ for a specific $[\mathrm{MiE}]$ is indicative for a higher concentration in the seaweed moisture in comparison to the oceanic water so it can be sequestered (active or passive). For more specific details see the M \& M section.

\begin{tabular}{|c|c|c|c|c|c|c|c|c|c|c|c|}
\hline $\begin{array}{c}\text { Sample } \\
\text { nr. }\end{array}$ & $\begin{array}{l}\text { Seaweed } \\
\text { Species }\end{array}$ & $\begin{array}{c}\mathrm{Cu}^{2+} \\
{[\mu \mathrm{g} / 1]}\end{array}$ & $\begin{array}{c}\mathrm{Al}^{3+} \\
{[\mu \mathrm{g} / 1]}\end{array}$ & $\begin{array}{c}\mathrm{Zn}^{2+} \\
{[\mu \mathrm{g} / 1]}\end{array}$ & $\begin{array}{c}\mathrm{Cd}^{2+} \\
{[\mu \mathrm{g} / 1]}\end{array}$ & $\begin{array}{c}\mathrm{Co}^{2+} \\
{[\mu \mathrm{g} / \mathrm{l}]}\end{array}$ & $\begin{array}{c}\mathrm{Cr}^{3+} \\
{[\mu \mathrm{g} / 1]}\end{array}$ & $\begin{array}{l}\mathrm{Mo}^{4+} \\
{[\mu \mathrm{g} / \mathrm{l}]}\end{array}$ & $\begin{array}{c}\mathrm{Ni}^{2+} \\
{[\mu \mathrm{g} / \mathrm{l}]}\end{array}$ & $\begin{array}{c}\mathrm{Pb}^{2+} \\
{[\mu \mathrm{g} / 1]}\end{array}$ & $\begin{array}{c}\text { SUM } \\
\text { MICRO } \\
\text { CATIONS }\end{array}$ \\
\hline & Threshold & 0.10 & 0.30 & 0.30 & 0.01 & 0.01 & 0.02 & 0.18 & 0.03 & 0.04 & \\
\hline \multirow[t]{2}{*}{ 1) } & Ulva lactuca & 330.75 & 153.00 & 1232.25 & 2.39 & 13.88 & 18.65 & 14.33 & 157.50 & 1.26 & 1924.00 \\
\hline & & 74.29 & 20.99 & 236.99 & 0.34 & 0.33 & 0.90 & 1.00 & 9.68 & 1.66 & 271.67 \\
\hline \multirow[t]{2}{*}{ 2) } & Caulerpa sertlaiodes & 117.85 & 582.75 & 1169.50 & 5.72 & 6.99 & 14.50 & 6.99 & 129.75 & 2.45 & 2036.49 \\
\hline & & 13.23 & 175.55 & 361.52 & 0.47 & 0.21 & 0.39 & 4.61 & 5.32 & 1.53 & 341.40 \\
\hline \multirow[t]{2}{*}{ 3) } & Caulerpa cf. brach. & 788.25 & 230.00 & 1136.00 & 4.43 & 22.13 & 20.23 & 8.54 & 295.25 & 1.33 & 2506.15 \\
\hline & & 69.21 & 46.45 & 146.50 & 0.22 & 0.22 & 1.25 & 0.35 & 9.36 & 0.95 & 257.38 \\
\hline \multirow[t]{2}{*}{ 4) } & Undaria pinnatifidia & 73.90 & 156.00 & 178.75 & 0.81 & 1.04 & 6.16 & 14.80 & 20.08 & 0.09 & 451.63 \\
\hline & & 12.78 & 9.93 & 18.45 & 0.13 & 0.12 & 0.27 & 3.00 & 3.89 & 0.15 & 44.40 \\
\hline \multirow[t]{2}{*}{$\begin{array}{c}\text { Sample } \\
\text { nr. }\end{array}$} & $\begin{array}{c}\text { Four } \\
\text { Oceans }\end{array}$ & $\begin{array}{l}\mathrm{Cu}^{2+} \\
{[\mu \mathrm{g} / \mathrm{l}]}\end{array}$ & $\begin{array}{c}\mathrm{Al}^{3+} \\
{[\mu \mathrm{g} / 1]}\end{array}$ & $\begin{array}{c}\mathrm{Zn}^{2+} \\
{[\mu \mathrm{g} / \mathrm{l}]}\end{array}$ & $\begin{array}{c}\mathrm{Cd}^{2+} \\
{[\mu \mathrm{g} / 1]}\end{array}$ & $\begin{array}{c}\mathrm{Co}^{2+} \\
{[\mu \mathrm{g} / \mathrm{l}]}\end{array}$ & $\begin{array}{c}\mathrm{Cr}^{3+} \\
{[\mu \mathrm{g} / 1]}\end{array}$ & $\begin{array}{l}\mathrm{Mo}^{4+} \\
{[\mu \mathrm{g} / \mathrm{l}]}\end{array}$ & $\begin{array}{c}\mathrm{Ni}^{2+} \\
{[\mu \mathrm{g} / \mathrm{l}]}\end{array}$ & $\begin{array}{c}\mathrm{Pb}^{2+} \\
{[\mu \mathrm{g} / 1]}\end{array}$ & $\begin{array}{c}\text { SUM } \\
\text { MICRO } \\
\text { CATIONS }\end{array}$ \\
\hline & Threshold & 0.10 & 0.30 & 0.30 & 0.01 & 0.01 & 0.02 & 0.18 & 0.03 & 0.04 & \\
\hline 1) & Netherlands & 0.13 & 0.30 & 0.30 & 0.01 & 0.01 & 0.01 & 2.07 & 0.03 & 0.04 & 2.90 \\
\hline 2) & Indonesia & 0.02 & 0.70 & 0.30 & 0.00 & 0.01 & 0.01 & 1.14 & 0.36 & 0.04 & 2.58 \\
\hline 3) & Cuba & 0.10 & 1.00 & 0.30 & 0.02 & 0.01 & 0.05 & 2.49 & 0.16 & 0.04 & 4.17 \\
\hline 4) & Ireland & 0.10 & 0.30 & 0.30 & 0.00 & 0.01 & 0.00 & 1.11 & 0.03 & 0.04 & 1.89 \\
\hline Mean & & 0.09 & 0.58 & 0.30 & 0.01 & 0.01 & 0.02 & 1.70 & 0.15 & 0.04 & 2.88 \\
\hline Std & & 0.05 & 0.34 & 0.00 & 0.01 & 0.00 & 0.02 & 0.69 & 0.16 & 0.00 & 0.95 \\
\hline \multirow[t]{2}{*}{ nr. } & $\begin{array}{c}\text { Ratio } \\
\text { seaweed/ocean }\end{array}$ & $\begin{array}{c}\mathrm{Cu}^{2+} \\
{[\mu \mathrm{g} / \mathrm{l}]}\end{array}$ & $\begin{array}{c}\mathrm{Al}^{3+} \\
{[\mu \mathrm{g} / 1]}\end{array}$ & $\begin{array}{c}\mathrm{Zn}^{2+} \\
{[\mu \mathrm{g} / 1]}\end{array}$ & $\begin{array}{c}\mathrm{Cd}^{2+} \\
{[\mu \mathrm{g} / \mathrm{l}]}\end{array}$ & $\begin{array}{c}\mathrm{Co}^{2+} \\
{[\mu \mathrm{g} / \mathrm{l}]}\end{array}$ & $\begin{array}{c}\mathrm{Cr}^{3+} \\
{[\mu \mathrm{g} / 1]}\end{array}$ & $\begin{array}{l}\mathrm{Mo}^{4+} \\
{[\mu \mathrm{g} / \mathrm{l}]}\end{array}$ & $\begin{array}{c}\mathrm{Ni}^{2+} \\
{[\mu \mathrm{g} / \mathrm{l}]}\end{array}$ & $\begin{array}{c}\mathrm{Pb}^{2+} \\
{[\mu \mathrm{g} / \mathrm{l}]}\end{array}$ & $\begin{array}{c}\text { SUM } \\
\text { MICRO } \\
\text { CATIONS }\end{array}$ \\
\hline & Threshold & 0.10 & 0.30 & 0.30 & 0.01 & 0.01 & 0.02 & 0.18 & 0.03 & 0.04 & \\
\hline \multirow[t]{2}{*}{ 1) } & Ulva/ocean & 2544.23 & 510.00 & 4107.50 & 199.17 & 1982.14 & 1865.00 & 6.92 & 5250.00 & 31.38 & 16496.34 \\
\hline & & 571.49 & 69.97 & 789.95 & 28.57 & 47.20 & 90.37 & 0.49 & 322.61 & 41.40 & 1281.90 \\
\hline \multirow[t]{2}{*}{ 2) } & Caulerpa sert./ocean & 3695.00 & 222.86 & 595.83 & 403.75 & 207.50 & 684.72 & 12.98 & 55.76 & 2.31 & 5880.72 \\
\hline & & 639.07 & 14.19 & 61.49 & 65.24 & 23.69 & 29.74 & 2.63 & 10.81 & 3.84 & 826.12 \\
\hline \multirow[t]{2}{*}{ 3) } & Caulerpa brach./ocean & 1.30 & 0.30 & 1.00 & 0.60 & 1.17 & 0.20 & 0.83 & 0.19 & 1.00 & 6.58 \\
\hline & & 0.00 & 0.00 & 0.00 & 0.00 & 0.00 & 0.00 & 0.00 & 0.00 & 0.00 & 0.00 \\
\hline \multirow[t]{2}{*}{ 4) } & Undaria/ocean & 0.20 & 2.33 & 1.00 & 0.50 & 1.00 & 2.25 & 1.03 & 12.00 & 1.00 & 21.31 \\
\hline & & 0.00 & 0.00 & 0.00 & 0.00 & 0.00 & 0.00 & 0.00 & 0.00 & 0.00 & 0.00 \\
\hline
\end{tabular}


Table 8. $\mathrm{pH} \& \mathrm{H}^{+}$-ions in [mol/l] with $\mathrm{pH}$ calculated according to [25]; $\mathrm{pH}=-\log \left[\mathrm{H}^{+}\right]$; nutrients $(\mathrm{N} \& \mathrm{P})$ like in seaweed moisture of four seaweed species [per species mean $\pm \mathrm{SD}, \mathrm{n}=4)$, in a water sample $(\mathrm{n}=1)$ of the local ocean and the seaweed/ocean ration for that microelement. The same remark for a ratio $>1$ for a specific element/compound. For more details see $M$ \& $M$ section.

\begin{tabular}{|c|c|c|c|c|c|c|c|c|}
\hline $\begin{array}{l}\text { Sample } \\
\text { nr. }\end{array}$ & $\begin{array}{l}\text { Seaweed } \\
\text { Species }\end{array}$ & $\begin{array}{l}\mathrm{H}^{+} \\
\text {Ions }\end{array}$ & $\mathrm{pH}$ & $\begin{array}{c}\mathrm{P}^{3-} \\
{[\mathrm{mg} / \mathrm{l}]}\end{array}$ & $\begin{array}{c}\mathrm{N}-\mathrm{NH} 4 \\
{[\mathrm{mg} / \mathrm{l}]}\end{array}$ & $\begin{array}{c}\left(\mathrm{NO}_{3}+\mathrm{NO}_{2}\right) \\
{[\mathrm{mg} / \mathrm{l}]}\end{array}$ & $\begin{array}{c}\text { N-total } \\
{[\mathrm{mg} / \mathrm{l}]}\end{array}$ & $\begin{array}{c}\text { Sum } \\
\text { nutrient }(\mathrm{N} \& \mathrm{P})\end{array}$ \\
\hline & Threshold & {$[\mathrm{mol} / \mathrm{l}]$} & $\mathrm{X}$ & 0.10 & 0.04 & 0.03 & 0.30 & \\
\hline \multirow[t]{2}{*}{ 1) } & Ulva lactuca & 0.64 & 5.06 & 0.00 & 0.00 & 0.01 & 0.20 & 0.21 \\
\hline & & 0.17 & 0.17 & 0.00 & 0.00 & 0.00 & 0.00 & 0.00 \\
\hline \multirow[t]{2}{*}{ 2) } & Caulerpa sertlaiodes & 1.66 & 4.19 & 0.02 & 0.02 & 0.86 & 1.00 & 1.90 \\
\hline & & 0.02 & 0.02 & 0.00 & 0.00 & 0.00 & 0.00 & 0.00 \\
\hline \multirow[t]{2}{*}{ 3) } & Caulerpa cf. Brach. & 2.65 & 4.51 & 0.79 & 0.02 & 14.10 & 14.70 & 29.61 \\
\hline & & 0.00 & 0.00 & 0.00 & 0.00 & 0.00 & 0.00 & 0.00 \\
\hline \multirow[t]{2}{*}{ 4) } & Undaria pinnatifidia & 4.12 & 6.51 & 0.01 & 0.04 & 0.01 & 0.20 & 0.26 \\
\hline & & 0.07 & 0.05 & 0.00 & 0.00 & 0.00 & 0.00 & 0.00 \\
\hline \multirow[t]{2}{*}{$\begin{array}{c}\text { Sample } \\
\mathrm{nr} .\end{array}$} & $\begin{array}{l}\text { Four } \\
\text { Oceans }\end{array}$ & $\begin{array}{l}\mathrm{H}^{+} \\
\text {Ions }\end{array}$ & $\mathrm{pH}$ & $\begin{array}{c}\mathrm{P}^{3-} \\
{[\mathrm{mg} / \mathrm{l}]}\end{array}$ & $\begin{array}{l}\mathrm{N}-\mathrm{NH}_{4} \\
{[\mathrm{mg} / \mathrm{l}]}\end{array}$ & $\begin{array}{c}\left(\mathrm{NO}_{3}+\mathrm{NO}_{2}\right) \\
{[\mathrm{mg} / \mathrm{l}]}\end{array}$ & $\begin{array}{l}\mathrm{N} \text {-total } \\
{[\mathrm{mg} / \mathrm{l}]}\end{array}$ & $\begin{array}{c}\text { Sum } \\
\text { nutrient }(N \& P)\end{array}$ \\
\hline & Threshold & {$[\mathrm{mol} / \mathrm{l}]$} & $\mathrm{x}$ & 0.10 & 0.04 & 0.03 & 0.30 & \\
\hline 1) & Netherlands & 0.25 & 8.29 & 0.02 & 0.04 & 0.03 & 0.20 & 0.29 \\
\hline 2) & Indonesia & 0.25 & 8.12 & 0.02 & 0.02 & 0.86 & 1.00 & 1.90 \\
\hline 3) & Cuba & 0.25 & 8.11 & 0.79 & 0.02 & 14.10 & 14.70 & 29.61 \\
\hline 4) & Ireland & 0.25 & 7.96 & 0.01 & 0.04 & 0.01 & 0.20 & 0.26 \\
\hline Mean & & 0.25 & 8.12 & 0.21 & 0.03 & 3.75 & 4.03 & 8.02 \\
\hline Std & & 0.13 & 0.13 & 0.39 & 0.01 & 6.91 & 7.13 & 14.42 \\
\hline \multirow[t]{2}{*}{$\begin{array}{l}\text { Sample } \\
\mathrm{nr} .\end{array}$} & $\begin{array}{c}\text { Ratio } \\
\text { seaweed/ocean }\end{array}$ & $\begin{array}{l}\mathrm{H}^{+} \\
\text {Ions }\end{array}$ & $\mathrm{pH}$ & $\begin{array}{c}\mathrm{P}^{3-} \\
{[\mathrm{mg} / \mathrm{l}]}\end{array}$ & $\begin{array}{c}\mathrm{N}-\mathrm{NH}_{4} \\
{[\mathrm{mg} / \mathrm{l}]}\end{array}$ & $\begin{array}{c}\left(\mathrm{NO}_{3}+\mathrm{NO}_{2}\right) \\
{[\mathrm{mg} / \mathrm{l}]}\end{array}$ & $\begin{array}{c}\text { N-total } \\
{[\mathrm{mg} / \mathrm{l}]}\end{array}$ & $\begin{array}{c}\text { Sum } \\
\text { nutrient }(\mathrm{N} \& \mathrm{P})\end{array}$ \\
\hline & Threshold & {$[\mathrm{mol} / \mathrm{l}]$} & $\mathrm{X}$ & 0.10 & 0.04 & 0.03 & 0.30 & \\
\hline \multirow[t]{2}{*}{ 1) } & Ulva/ocean & 7.32 & 0.61 & 0.05 & 0.03 & 0.33 & 1.00 & 1.41 \\
\hline & & 0.02 & 0.02 & 0.00 & 0.00 & 0.00 & 0.00 & 0.00 \\
\hline \multirow[t]{2}{*}{ 2) } & Caulerpa sert./ocean & 2.25 & 0.80 & 0.50 & 2.00 & 0.01 & 0.20 & 2.71 \\
\hline & & 0.01 & 0.01 & 0.00 & 0.00 & 0.00 & 0.00 & 0.00 \\
\hline \multirow[t]{2}{*}{ 3) } & Caulerpa brach./ocean & 1.34 & 1.02 & 0.03 & 2.00 & 0.00 & 0.01 & 2.04 \\
\hline & & 0.00 & 0.00 & 0.00 & 0.00 & 0.00 & 0.00 & 0.00 \\
\hline \multirow[t]{2}{*}{ 4) } & Undaria/ocean & 1.35 & 1.02 & 2.00 & 0.50 & 86.00 & 5.00 & 93.50 \\
\hline & & 0.00 & 0.00 & 0.00 & 0.00 & 0.00 & 0.00 & 0.00 \\
\hline
\end{tabular}


to maintain suitable ion levels by minimizing the influx of $\mathrm{Na}^{+}$ions into cells via $\mathrm{Na}^{+}$-ATPase activity. In principle there are three major mechanisms a seaweed can apply in order to cope with the problem of salt stress in the euhaline oceanic environment [15].

First, $\mathrm{Na}^{+}$sequesters in vacuoles within the lumen of the seaweed thallus in such a safe way that this salt is spatially separated from vital plant physiological and biochemical mechanisms. A cell-to-cell channel e.g. in case of the $\mathrm{Na}^{+}$sequestering in special vacuoles within the lumen of the seaweed thallus with vacuoles for $\mathrm{Na}^{+}$storage spatially separated from vital seaweed organelles like the nucleus, chloroplast with its essential enzymes for photosynthesis and mitochondria for vital plant physiological and biochemical mechanisms. While some seaweeds appear to minimize the influx of ions into cells, ion sequestering within vacuoles is still essential in maintaining osmotic equilibrium, in support of $\mathrm{Na}^{+}$accumulation in vacuoles. In these plants, ATPases mediate the translocation of $\mathrm{H}^{+}$and $\mathrm{K}^{+} / \mathrm{Na}^{+}$, and were found to increase in number during salt stress [16] [26]. It is also possible that ATPases with a greater affinity for $\mathrm{K}^{+}$may be actively involved in ion influx, while a second type of ATPase transporter, with lower $\mathrm{K}^{+} \mathrm{Na}^{+}$selectivity, is pumping ions in the other direction [12] [16]. As a consequence that seaweeds have to live in a harsh euhaline [15] oceanic environment they must undergo osmotic adjustment involving, in part, the localization of toxic ions (typically $\mathrm{Na}^{+}$and $\mathrm{Cl}^{-}$) into vacuoles and away from important metabolic processes located within the cytoplasm [12] [21]. This spatially separation is in case of the $\mathrm{Na}^{+}$ion based on diminishing the deleterious effects of sodium on inner membrane plant physiological parameters.

The [Wet weight/Dry weight] ratio WW/DW is a morphological parameter to make a comparison between seaweeds species possible to estimate the vacuole capacity and thus the water storage capacity. By using this mechanical pressure method until 10 bar we have to consider, we obtained seaweed moisture from two types of vacuoles: first, vacuoles from the epidermal cells with proportionally smaller vacuoles and secondly from the highly vacuolated mesophyll cells [27]. Beyond inner seaweed species differences in total vacuole and water-storage ( $\approx$ seaweed moisture) capacity, within a seaweed species also the ratio between the two types of vacuoles may determine its water storage capacity. In addition, a high WW/DW ratio is a reflection of larger vacuoles for storage and the presence of a higher water content in the cell wall which may facilitate the accumulation of heavy metals (microelements) into the apparent free space by dilution [28]. Direct indications that seaweeds can cope with salt stress by $\mathrm{Na}^{+}$ accumulation within vacuoles within the lumen of the seaweed thallus came from field data; the study of [29] was in a brown seaweed based on the salt content of the cell wall components (Dry Weight) constituted up to $40 \%-47 \%$ of the dry weight of seaweed biomass. This latter observation is indicative that $\mathrm{Na}^{+}$ ions are spatially separated in the seaweed cell from vital (enzymatic) systems.

Secondly, active or passive extrusion of $\mathrm{Na}^{+}$to the oceanic environment followed by finding solutions by absorption (passive or active) of several com- 
pounds Heavy Metals [HM] and nutrients like $\mathrm{N} \& \mathrm{P}$ or the ion $\mathrm{K}^{+}$from the oceanic environment which can act as osmolyticum so that ionic homeostasis is maintained. Even with the disparity between $\mathrm{Na}^{+}$and $\mathrm{K}^{+}$concentrations in seawater at all four oceanic locations of $\approx 30$ with of course $\left[\mathrm{K}^{+}\right] \approx 30$ fold lower) our seaweeds are able to accumulate comparatively high levels of $\mathrm{K}^{+}$within their tissues which correspond to the values for seagrasses (Table 5) [16] [30]. These differences may reflect some general variations in physiological processes involved in salt tolerance. For example, while seaweeds accumulate relatively high $\mathrm{Na}^{+}$concentrations, they also concentrate remarkably high $\mathrm{K}^{+}$levels; resulting in a $\left[\mathrm{Na}^{+}: \mathrm{K}^{+}\right]$molar ratio of 1.25 ([18], [19] see Table 1 introduction). The results of our study indicate that this is not the general case because we found in two Caulerpa spp. intermediate values of $\approx 11.5$ (range 9.9 - 13.0), while in the brown seaweed Undaria pinnatifidia a $\left[\mathrm{Na}^{+}: \mathrm{K}^{+}\right]$molar ratio of $\approx 26$.

Third, production by several specific adapted seaweed species of economical important osmolyticum after sodium extrusion is a rather metabolically and energetically expensive method which also from a biochemical point of view much has evolved during course of evolution in some specific seaweed species. It is a much "cheaper" way simply to exchange the extruded sodium ions with an osmolyticum which is already available in the oceanic environment like Heavy Metals and nutrients like N \& P. However, during course of evolution some seaweed species "has chosen" for this option, which is nowadays in gratitude explored by industry because these osmolyticum compounds have many purposes and of extremely economic importance. Osmolytica like alginates and carrageenan are mainly produced by brown seaweeds while agar is mainly produced by red seaweeds. From the carbohydrate fraction these alginates are important cell wall component in all brown seaweed spp. constituting up to $40 \%-47 \%$ of the dry weight of seaweed biomass. The alginates and their oxidation products the sugar-diacides are employed by seaweeds as a sequestering mechanism for heavy metals $[\mathrm{HM}]$ in the seaweed moisture. From the phycocoloid fraction carrageenans are a group of biomolecules composed of linear polysaccharide chains with sulphate half-esters attached to the sugar unit. These properties allow carrageenans to dissolve in water, form highly viscous solutions and remain stable over a wide $\mathrm{pH}$ range. Especially the brown seaweeds Chondrus crispus and Kappaphycus spp. can contain up to $71 \%$ and $88 \%$ of carrageenan, respectively. The other osmolyticum from the phycocoloid fraction -but in contrast to carrageenans extracted from red seaweed such as Gelidium spp. and Gracilaria spp. is agar. Agar is a mixture of polysaccharides, which can be composed of agarose and agropectin, with similar structural and functional properties as carrageenans. The agar content in Gracilaria spp. can reach values up to $31 \%$ [31].

Salt extrusion to the oceanic environment in exchange with a certain compound like metallic cations (Heavy metals $[\mathrm{HM}]$ ) which serve as kind of osmolyticum to maintain cell integrity [18] [19], see also Table 2.

A third adaptation mechanism in some specific seaweeds (mainly red \& brown) to salt extrusion is the production of its own osmolyticum. The several 
produced osmolytical compounds are in an extensive detailed manner mentioned by [14]. She grouped the several compounds as follows: First, products of the photosynthesis (polyols and amino acids) Secondly, several solutes derived from the quaternary type ammonium compounds and tertiary sulphonium compouds (see further discussion: salt tolerance of Ulva lactuca and ROS scavening DMSP) Third, osmolytica from the carbohydrate fraction of seaweeds consisting mainly out of: alginates, laminarine and fucoidine [14]. In addition, osmolytica from the phycocolloids fraction are mentioned with two economical important major groups: carrageenan and agar (reviewed: [31]).

The permeability of biological membranes is highly selective. The flow of molecules and ions between a cell and its environment is regulated by specific transport systems which will be exemplified under A: Active and B: Passive. These transport systems have several important roles: 1) They regulate cell volume and maintain the intracellular $\mathrm{pH}$ and ionic composition within a narrow range to provide a favorable environment for enzyme activity; 2) The molecular mechanism of many transport processes is a very actual research area. With respect to seaweeds and other marine plants it is a nearly unexplored research area [32] [33].

A: Active Of all transport mechanisms over the cell membrane the ATP driven $\mathrm{Na}^{+} / \mathrm{K}^{+}$is the best described. For seaweeds in high saline environments it is believed that $\mathrm{Na}^{+}$can cross the plasma membrane using the same transport systems developed for $\mathrm{K}^{+}$[21] [22] [34] There are a number of ions and channels involved for on transport processes used in plants to achieve osmotic homeostasis. The primary ions involved in osmotic adjustment are $\left(\mathrm{Ca}^{2+}, \mathrm{Cl}^{-}, \mathrm{H}^{+}, \mathrm{K}^{+}\right.$, and $\mathrm{Na}^{+}$) These ion levels in the cytoplasm must be must be carefully controlled to prevent metabolic disruptions [16] [30]. The efflux of cytosolic $\mathrm{Na}^{+}$(either outside the cell or into a vacuole) may be accomplished through electroneutral $\mathrm{Na}^{+} / \mathrm{H}^{+}$antiporters that depend on energy from $\mathrm{H}^{+}$-ATPases along the plasmalemma or tonoplast [16] [23]. However, because of thermodynamic restrictions, $\mathrm{Na}^{+} / \mathrm{H}^{+}$antiporters cannot effectively transport $\mathrm{Na}^{+}$outside the cell when the $\mathrm{pH}$ of the external medium is relatively high like in seawater [25], while alternative transport systems have been described in other organisms, such as $\mathrm{Na}^{+}$-ATPase in seaweeds [16].

This pump has two purposes:

B: Passive Many transport processes are not directly driven by the hydrolysis of ATP. Instead, they are coupled to the flow of an anion down its electrochemical gradient. An example is facilitated diffusion without any ATP costs. Overall, theoretically several mechanisms for transport of ions over cell membranes are possible. These are transporters (or carrier) proteins which can move a single type of molecule in one direction across the cell membrane (a uniporter), several different molecules in one direction (a symporter) or different molecules in opposite directions (an antiporter) [33]. Transporters can allow the movement of molecules down chemical concentration gradients (facilitated diffusion), when the energy required for conformational changes in the transporter protein is 
provided by the concentration gradient rather than by metabolic activity [33].

This probably can be ascribed to proton transport across the plasma membrane and tonoplast driven by electrochemical gradients produced thus ATP-driven by $\mathrm{H}^{+}$pumps ratio: $\left[\mathrm{H}^{+}\right.$seaweed]/[ $\mathrm{H}^{+}$ocean] [16] [35] [36] [37]. This secondary transport will assist in the uptake of protons from the oceanic environment inwards the seaweed cell with its vacuole. The development and maintenance of $\mathrm{H}^{+}$electrochemical gradients are achieved through $\mathrm{H}^{+}$-ATPases in the plasma membrane and $\mathrm{H}^{+}$-ATPases and $\mathrm{H}^{+-}$pyrophosphatases in the tonoplast [23]. While $\mathrm{H}^{+}$-pyrophosphatases are important in the transport of $\mathrm{H}^{+}$into the vacuole, its role in salt tolerance is unclear. It is believed that the primary physiological responsibilities of $\mathrm{H}^{+}$-pyrophosphatase are to maintain cytosolic $\mathrm{pH}$ and to regulate pyrophosphate turnover [16] [23] [35].

From all four investigated seaweeds Ulva lactuca has probably the highest tolerance for salt stress. From the study of [38] it became clear that good growth of germlings and young blades of all studies five Ulva sp. in the Netherlands occurred in a wide variety of salinity (mainly 17\%o - 34\%o), and didn't show a distinct correlation with differences in salinity the adult plants were exposed to at their natural habitats [38]. In general it can be stated that the UIvales poses an extreme salt tolerance covering a wide range/spectrum 17\%o - 34\%o [39]. U. lactuca adapts to salinity with changes in $\mathrm{K}^{+}, \mathrm{Na}^{+}$and $\mathrm{Cl}^{-}$. Hypo-osmotic stress decreased the tissue concentration of $\mathrm{K}^{+}, \mathrm{Na}^{+}$and $\mathrm{Cl}^{-}$while hyper-osmotic stress caused a transient increase in $\mathrm{Na}^{+}$and a stable accumulation of $\mathrm{K}^{+}$and $\mathrm{Cl}^{-}$[40]. Also $\beta$-dimethylsulphoniopropionate (DMSO)-previously reported in the literature with $\beta$-dimethylpropiothetin is important in osmotic adaptation of $U$. lactuca [40]. This sulphonium compound may well cause the characteristic sulphuric smell that accompanies Ulva blooms at the beaches in summer time like in Brittany [41]. In addition, because of this salinity tolerance of Ulva, with intra-cellular concentrations of $\mathrm{K}^{+} 20$-fold higher than in seawater and an intra-cellular ratio between $\mathrm{Na}^{+}$and $\mathrm{K}^{+}$lower than in human metabolic waste, it has been suggested that Ulva sp. is a good candidate species for space agriculture, recycling human material [42]. This extreme salinity tolerance of Ulva spp. ( $U$. fasciata) can also possibly be ascribed to the highly effective antioxidant defense mechanism against salinity stress [43]. During salinity stress of Ulva spp., free oxygen radicals arise during metabolism in the mitochondria. These reactive oxygen species (ROS) are partly neutralized by antioxidant defense mechanisms. During salinity stress, those defense mechanisms are not completely effective, and so a fraction of ROS escape and cause molecular damage. This may be one factor underlying salinity stress. Superoxide Dismutase (SOD) is an interesting enzyme. This enzyme, present in the cytosol $(\mathrm{Cu}-\mathrm{Zn}$ containing form) and mitochondrial matrix (Mn-containing form) of the cells of aerobic organisms, serves the function of converting superoxide anion radicals $\left(\mathrm{O}_{2}^{-}\right)$into $\mathrm{H}_{2} \mathrm{O}_{2}$ and oxygen [43]. The main assumption of salinity stress is that the normal levels of antioxidant defenses are not fully efficient to neutralize "reactive oxygen species" (ROS) and that a fraction of ROS escapes elimination, causing irreparable 
molecular damage. Also catalase and several types of peroxidases are involved in $\mathrm{H}_{2} \mathrm{O}_{2}$ removal [43]. This mechanism of scavenging ROS and preventing and repairing the damaging effects on macromolecules is critical for salt tolerant plants [43].

On one hand we have seaweed species (genetic) influences which we will elucidate in future studies by determination of species specific characteristics in the biochemical composition of the seaweed cell wall. The involved cell wall constituents for the three different seaweed Phyla (green, brown, red) are mentioned below.

1) For green seaweeds (three of our investigated species) the cell wall contains sulphuric acid polysaccharides, sulphated galactans and xylans,

2) For brown seaweeds like in this study Undaria pinnatifidia the cell wall consists of compounds like alginic acid, fucoidan (sulphated fucose), laminarin ( $\beta-1,3$ glucan) and sargassan,

3) For red seaweeds the cell wall contains agars, carrageenans, xylans, floridean starch (amylopectin-like glucan), water-soluble sulphated galactan.

The cell walls of all these thousands of seaweeds are species-specific. So in our investigation of the topic of salt extrusion of the four selected seaweeds some of the different observation possibly can be explained by seaweed species characteristics. Just like we earlier published that for seaweed lipid compositions (the several $\Omega-3$ and $\Omega-6$ poly-unsaturated acids (PUFA's), as well as its $\Omega-6 / \Omega-3$ ration), both quantitatively as qualitatively were to a major extent seaweed species (genus) dependent, to a minor extent also an environmental effect [44]. Also another example can exemplify the seaweed species dependents (genetic component) effect. For glucose content in 50 individual plants of Saccharina sp.; a combined sample of Fucus serratus \& Fucus spiralis and Ascophyllum nodusum its concentration in an autumn sample was respectively $65 \%, 30 \%$ and $20 \%$ which is a clear indication for a species effect (reviewed: [31]).

Perspectives: While terrestrial agriculture is presently at its limits [1], seaweed culture has great promises for humanity [45] [46]. In modern agriculture, all seaweed compensation mechanisms employed to cope with oceanic euhaline $(32 \%$ ) salinity stress can have practical purposes in large seaweed plantations and can be explored to create urgently in order to create large amounts of irrigation water in order to obtain new agricultural area in our tropical deserts like the Sahara. Some of these seaweed adaptation mechanisms are: 1) Produce by mechanical pressure large amounts of brackish seawater $\approx 10 \%$ available in the seaweed milieu interior which can further be desalinated until fresh (0\%) irrigation water by fermentation of the remaining $20 \%$ green biomass "press-cake"; 2 ) This seaweed moisture contains high concentration of nutrients ( $\&$ P) sequestered from the eutrophic oceans; 3) Sequestering of $\mathrm{H}^{+}$ions from the oceanic environment to combat ocean acidification [46]; 4) Produce large amounts of new green biomass on planet Earth by exploring our oceans by seaweed plantations to act as sink for $\mathrm{CO}_{2}$ to combat "Global Earth warming" [47], in combination with "ocean acidification" [25] [46]. These practical applications will be de- 
scribed in another manuscript.

\section{References}

[1] Foresight (2011) The Future of Food and Farming. Final Project Report, Government Office for Science, London, 208 p.

[2] van Ginneken, V. and de Vries, E. (2015) Towards a Seaweed Based Economy. Journal of Fisheries Sciences, 9, 85-88.

[3] van Ginneken, V. and de Vries, E. (2016) Towards a Seaweed Based Economy: The Global Ten Billion People Issue at the Midst of the 21st Century. Journal of Fisheries Sciences, 10, 1-11.

[4] van Ginneken, V., de Vries, E. and Wijgerde, T. (2015) A Suggested "Seaweed-Plantation Model" to Tackle the Looming Phosphorus Crises in the 21 st Century at the Rhine/North Sea System. Journal of Fisheries Sciences, 9, 105-114.

[5] Näsholm, T., Kielland, K. and Ganeeteg, U. (2009) Uptake of Organic Nitrogen by Plants. New Phytologist, 182, 31-48. https://doi.org/10.1111/j.1469-8137.2008.02751.x

[6] Guttman, L. and Neori, A. (2017) Thoughts on Algae Cultivation toward an Expansion of Aquaculture to the Scale of Agriculture. In: Butu, A., Lakatos, A. and Bulsura, P., Eds., Proceedings of 7 th International Conference on Innovation in Chemical, Agricultural, Biological and Environmental Sciences, Chapter. Thoughts on Algae Cultivation toward an Expansion of Aquaculture to the Scale of Agriculture, HEAIG Group, 38-43.

[7] Spilhaus, A.F. (1942) Maps of the Whole World Ocean. Geographical Review, 32, 431-435.

[8] Munns, R. (2002) Comparative Physiology of Salt and Water Stress. Plant, Cell and Environment, 25, 239-250. https://doi.org/10.1046/j.0016-8025.2001.00808.x

[9] Hurd, C.L., Harrison, P.J., Bishof, K. and Lobban, C.S. (2014) Seaweed Ecology and Physiology. 2nd Edition, Cambridge University Press, Cambridge, 551 p. https://doi.org/10.1017/CBO9781139192637

[10] van Ginneken, V. (2017) The Photosynthetic System of the Seaweeds: The Seaweed Paradox Asian. Journal of Science and Technology, 8, 6567-6571.

[11] Buschmann, A.H., Camus, C., Infante, J., Neori, A., Israel, Á., Hernández-González, M.C., Pereda, S.V., Gomez-Pinchetti, J.L., Golberg, A., Tadmor-Shalev, N. and Critchley, A.T. (2017) Seaweed Production: Overview of the Global State of Exploitation, Farming and Emerging Research Activity. European Journal of Phycology, 52, 391-406. https://doi.org/10.1080/09670262.2017.1365175

[12] Yeo, A.R. (1998) Molecular Biology of Salt Tolerance in the Context of Whole Plant Physiology. Journal of Experimental Botany, 49, 915-929. https://doi.org/10.1093/jxb/49.323.915

[13] Mahajan, S. and Tuteja, N. (2005) Cold, Salinity and Drought Stresses: An Overview. Archives of Biochemistry and Biophysics, 444, 139-158. https://doi.org/10.1016/j.abb.2005.10.018

[14] Kirst, G.O. (1989) Salinity Tolerance of Eukaryotic Marine Algae. Annual Review of Plant Physiology and Plant Molecular Biology, 40, 21-53.

[15] Venice System (1958) Symposium on the Classification of Brackish Waters, Venice, April 8-14, 1958. Archives Oceanography and Limnology, Vol. 11, 1-248.

[16] Touchette, B.W. (2007) Seagrass-Salinity Interactions: Physiological Mechanisms Used by Submersed Marine Angiosperms for a Life at Sea. Journal of Experimental 
Marine Biology and Ecology, 350, 194-215.

https://doi.org/10.1016/j.jembe.2007.05.037

[17] Riley, J.P. and Chester, R. (1989) Introduction to Marine Chemistry. Academic Press, New York.

[18] Rupérez, P. (2002) Mineral Content of Edible Marine Seaweeds. Food Chemistry, 79, 23-26. https://doi.org/10.1016/S0308-8146(02)00171-1

[19] Zubia, M., Payri, C.E., Deslandes, E. and Guezennec, J. (2003) Chemical Composition of Attached and Drift Specimens of Sargassum mangarevense and Turbinaria ornata (1266) (Phaeophyta: Fucales from Tahiti, French Polynesia). Botanica Marina, 46, 562-571. https://doi.org/10.1515/BOT.2003.059

[20] Palmgren, M.G. (2001) Plant Plasma Membrane $\mathrm{H}^{+}$-ATPases: Powerhouses for Nutrient Uptake. Annual Review of Plant Physiology and Plant Molecular Biology, 52, 817-845. https://doi.org/10.1146/annurev.arplant.52.1.817

[21] Niu, X., Bressan, R.A., Hasegawa, P.M. and Pardo, J.M. (1995) Ion Homeotasis in $\mathrm{NaCl}$ Stress Environments. Plant Physiology, 109, 735-742.

https://doi.org/10.1104/pp.109.3.735

[22] Blumwald, E., Aharaon, G.S. and Apse, M.P. (2000) Sodium Transport in Plant Cells. Biochimica et Biophysica Acta, 1465, 140-151. https://doi.org/10.1016/S0005-2736(00)00135-8

[23] Hasegawa, P.M., Bressan, R.A., Zhu, J.-K. and Bohnert, H.J. (2000) Plant Cellular and Molecular Responses to High Salinity. Annual Review of Plant Physiology, and Plant Molecular Biology, 51, 463-499. https://doi.org/10.1146/annurev.arplant.51.1.463

[24] Arroyo, J.A. (2003) Water Desalination. LBG-Guyton Associates, Brackish Groundwater Manual for Texas Regional Water Chapter 15, 293-302.

http://www.twdb.texas.gov/publications/reports/contracted_reports/doc/200148339 5.pdf

[25] Royal Society (2005) Ocean Acidification Due to Increasing Atmospheric Carbon Dioxide. Policy Document 12/05, London, 60 p.

[26] Watad, A.A., Reuveni, M., Bressan, R.A. and Hasegawa, P.M. (1991) Enhanced Net $\mathrm{K}^{+}$Uptake Capacity of NaCl-Adapted Cells. Plant Physiology, 95, 1265-1269. https://doi.org/10.1104/pp.95.4.1265

[27] Ye, C.J. and Zhao, K.F. (2003) Osmotically Active Compounds and Their Localization in the Marine Halophyte Eelgrass. Biologia Plantarum, 46, 137-140. https://doi.org/10.1023/A:1022380824938

[28] Fritioff, Å., Kautsky, L. and Greger, M. (2005) Influence of Temperature and Salinity on Heavy Metal Uptake by Submersed Plants. Environmental Pollution, 133, 265-274. https://doi.org/10.1016/j.envpol.2004.05.036

[29] Arasaki, S. and Arasaki, T. (1983) Low Calorie, High Nutrition Vegetables from the Sea to Help You Look and Feel Better. Japan Publications, Tokyo, 196 p.

[30] van Diggelen, J., Rozema, J. and Broekman, R. (1987) Mineral Composition of and Proline Accumulation by Zostera marina L in Response to Environmental Salinity. Aquatic Botany, 27, 169-176. https://doi.org/10.1016/0304-3770(87)90064-7

[31] Løvstad-Holdt, S. and Kraan, K. (2011) Bioactive Compounds in Seaweed: Functional Food Applications and Legislation. Journal of Applied Phycology, 23, 543-597. https://doi.org/10.1007/s10811-010-9632-5

[32] Acquino, R.S., Grativol, C. and Mourão, P.A.S. (2011) Rising from the Sea: Correlation between Sulfated Polysaccharides and Salinity in Plants. PLOS ONE, 6, e18862. 
https://doi.org/10.1371/journal.pone.0018862

[33] Berg, J.M., Stryer, L., Tymoczko, J.L. and Gatto, G.J. (2015) Biochemistry. 8th Edition, WH Freeman, 1120 p.

[34] Amtmann, A. and Sanders, D. (1999) Mechanism of $\mathrm{Na}^{+}$Uptake by Plant Cells. Advances in Botanical Research, 29, 75-112. https://doi.org/10.1016/S0065-2296(08)60310-9

[35] Zhien, R.G., Kim, E. and Rea, P.A. (1997) The Molecular and Biochemical Basis of Pyrophosphate-Energized Ion Translocation at the Vacuolar Membrane. Advances in Botanical Research, 27, 297-337. https://doi.org/10.1016/S0065-2296(08)60156-1

[36] Lüttge, U. and Ratajczak, R. (1997) The Physiology, Biochemistry, and Molecular Biology of the Plant Vacuolar ATPase. Advances in Botanical Research, 25, 253-296. https://doi.org/10.1016/S0065-2296(08)60155-X

[37] Palmgren, M.G. and Harper, J.F. (1999) Pumping with Plant P-Type ATPases. Journal of Experimental Botany, 50, 883-893. https://doi.org/10.1093/jxb/50.Special_Issue.883

[38] Koeman, R.P.T. and van den Hoek (1980) The Taxonomy of Ulva (Chlorophyceae) in the Netherlands. British Phycological Journal, 16, 9-53. https://doi.org/10.1080/00071618100650031

[39] Waite, T. and Mitchell, R. (1972) The Effect of Nutrient Fertilization on the Benthic Alga Ulva lactuca. Botanica Marina, 15, 151-156. https://doi.org/10.1515/botm.1972.15.3.151

[40] Dickson, D.M., Jones, R.G.W. and Davenport, J. (1980) Steady State Osmotic Adaptation in Ulva lactuca. Planta, 150, 158-165.

https://doi.org/10.1007/BF00582360

[41] Merceron, M. and Morand, P. (2004) Existence of a Deep Subtidal Stock of Drifting Ulva in Relation to Intertidal Algal Mat Developments. Journal of Sea Research, 52, 269-280. https://doi.org/10.1016/j.seares.2004.05.002

[42] Yamashita, M., Tomita-Yokotani, K., Hashimoto, H., Sawaki, N. and Notoya, M. (2009) Sodium and Potassium Uptake of Ulva-Application of Marine Macro-Algae for Space Agriculture. Advances in Space Research, 43, 1220-1223.

https://doi.org/10.1016/j.asr.2009.02.004

[43] Lu, I.-F., Sung, M.-S. and Lee, T.-M. (2006) Salinity Stress and Hydrogen Peroxide Regulation of Antioxidant Defense System in Ulva fasciata. Marine Biology, 150, 1-15. https://doi.org/10.1007/s00227-006-0323-3

[44] van Ginneken, V.J.T., Helsper, J.P.F.G., de Visser, W., van Keulen, H. and Brandenburg, W.A. (2011) Polyunsaturated Fatty Acids from North Atlantic and Tropical Seas. Lipids in Health and Disease, 10, 104-111. https://doi.org/10.1186/1476-511X-10-104

[45] Cottier-Cook, E.J., et al. (2016) Safeguarding the Future of the Global Seaweed Aquaculture Industry. United Nations University, Institute for Water, Environment and Health, UNU-INWEH \& Scottish Association for Marine Science, 12 p.

[46] Chung, I.-K., Sondak, C.F.A. and Beardall, J. (2017) The Future of Seaweed Aquaculture in a Rapidly Changing World. European Journal of Phycology, 52, 495-505.

[47] Raven, J.A. (2017) The Possible Roles of Algae in Restricting the Increase in Atmospheric $\mathrm{CO}_{2}$ and Global Temperature. European Journal of Phycology, 52, 506-522. 